\title{
PENGARUH PELATIHAN OUTBOND TERHADAP PENINGKATAN TIM KERJA GURU MADRASAH TSANAWIYAH “JB"
}

\section{THE INFLUENCE OF OUTBOND TRAINING TOTHE ENHANCEMENT OF TEACHER TEAMWORK OF MADRASAH TSANA WIYAH "JB"}

\author{
Rizqi Syafrina \\ H. Fuad Nashori \\ Ratna S. Rachmahana \\ Fakultas Psikologi dan IImu Sosial Budaya Universitas Islam Indonesia Yogyakarta \\ E-mail: nonon11185@gmail.com
}

\begin{abstract}
This research aimed at finding the influence of outbound training to the Madrasah Tsanawiyah "JB"'s teacher teamwork. The subject of this research was all teachers of Madrasah Tsanawiyah "JB". During the research, there were eight of 14 teachers that ever present in the whole training sessions. Meanwhile, the rest of the teachers did not attend the training due to their own personal agenda. The data was collected by using questionnaire of scale for teacher teamwork, and by observation using the anecdotal method and rating scale, and semi-structured interview. This research used the one group Pretest-Postest Design. In addition, the data analysis was conducted by using quantitative analysis of two related sample test with wilcoxon test and individual data analysis using visual inspection. This research found that outbound training can enhance the teacher teamwork. This was signaled by the team in the second week after joining the outbound training, in which it was found that Sig value was 0.018 (sig value $<0.05$ ) meaning that the hypothesis was proven: there was a difference in teacher teamwork before (pre-test stage) and two weeks after the training (follow-up stage).
\end{abstract}

Keywords: Outbound Training, Teacher Teamwork

\begin{abstract}
ABSTARAK
Penelitian ini bertujuan untuk mengetahui pengaruh pelatihan outbound terhadap peningkatan tim kerja guru Madrasah Tsanawiyah "JB". Subjek dalam penelitian ini adalah semua guru di Madrasah Tsanawiyah "JB".Pada pelaksanaan penelitian guru yang dapat mengikuti pelatihan dari awal sampai akhir pelatihan ada delapan subjek, dari 14 subjek.Sedangkan guru yang tidak dapat mengikuti pelatihan sepenuhnya dikarenakan alasan individu masing-masing. Pengumpulan data dilakukan dengan menggunakan skala tim kerja guru, observasi dengan menggunakan metode anecdotal record dan rating scale, dan wawancara semi terstruktur. Desain penelitian yang digunakan adalah The one Group Pretest-postest Design. Analisis data yang digunakan adalah analisis kuantitatif two related sample test dengan uji wilcoxon dan analisis data individu dengan visual inspection. Hasil penelitian yaitu pelatihan outbound dapat meningkatkan tim kerja guru. Hal ini ditunjukkan dari tim kerja guru dilihat hasilnya dua minggu setelah pelatihan (follow up) diketahui nilai Sig 0,018 (nilai sig < 0,05) yang berarti hipotesis diterima yaitu ada perbedaan tim kerja guru sebelum pelatihan (prates) dan dua minggu setelah pelatihan (follow up).
\end{abstract}

Kata kunci: Pelatihan Outbound, Tim Kerja Guru 
Sekolah merupakan tempat seseorang menuntut ilmu. Sekolah sebagai organisasi pendidikan menjadi tempat berlangsungnya proses belajar mengajar untuk tujuan pembangunan nasional. Keberhasilan tujuan pendidikan di sekolah tergantung pada sumber daya manusia yang ada di sekolah tersebut, yaitu kepala sekolah, guru, siswa, pegawai tata usaha, dan tenaga kependidikan lainnya. Selain sumber daya manusia juga didukung dengan sarana dan prasarana sekolah. Untuk membentuk manusia yang memiliki kualitas, diperlukan tenaga pendidik yang berkualitas. Hal ini berkaitan erat dengan profesi guru.

Untuk mewujudkan tujuan pendidikan dalam sebuah sekolah diperlukan kerja sama antar sesama guru. Hal ini sesuai dengan yang ungkapan Ancok (2002) bahwa sukses dalam pencapaian tujuan organisasi sangat ditentukan oleh kerja sama antar sesama anggota organisasi. Struktur organisasi yang terkotak-kotak dengan pembagian kerja yang sangat kaku membuat kelancaran interaksi sosial antar staf dalam organisasi menjadi terhambat (Ancok, 2002). Selain itu jarak antara kepala sekolah dan guru menjadi lebar dan keintiman dalam bekerja menjadi kurang. Hal ini pula yang akhirnya menyebabkan kurang adanya kerja sama antar guru dan menjadikan organisasi sekolah terhambat dalam mencapai tujuan pendidikan nasional. Dee dan
Henkin (Risfandy \& Suprapti, 2009) mengatakan di sekolah ada tim kerja di mana guru dapat bekerja sama dalam penyelesaian masalah, pembagian tanggung jawab, dan mempelajari tanggung jawab baru. Tim kerja sendiri menurut Kamus Besar Bahasa Indonesia (2012) dapat diartikan sebagai kerja sama antaranggota kelompok secara teratur dan baik. Menurut Kirkman dan Rosen (Risfandy \& Suprapti, 2009), kerja sama di sekolah yang dikelola sendiri dipercaya memiliki peranan yang penting sehingga guru dapat mengembangkan potensinya.

Tujuan sekolah dapat tercapai bila guru-guru di sekolah memiliki tim kerja yang baik. Bila di sekolah terdapat tim kerja yang baik, maka dapat meningkatkan komitmen guru terhadap sekolah. Hal ini sesuai dengan penelitian yang dilakukan oleh Risfandy dan Suprapti (2009) bahwa partisipasi dalam tim kerja memiliki pengaruh positif secara signifikan pada komitmen guru terhadap sekolahnya. Park dkk (2005) mengatakan bahwa kerja sama merupakan salah satu hal yang memengaruhi komitmen guru. Bila kerja sama guru kurang efektif, maka akan mempempengaruhi komitmen dan kinerja guru.

Hasil penelitian lain juga menunjukkan bahwa kerja sama tim memengaruhi kinerja organisasi (Lundstorm dkk, 2002). Penelitian yang dilakukan Nielsen (2008) juga 
mengatakan kalau kerja sama dalam tim memberikan kontribusi pada guru untuk bekerja dan diperlukan untuk melakukan pengajaran. Bila guru saling berbagi informasi mengenai metode pengajaran, maka kemampuan guru dalam mengajar semakin meningkat. Selain meningkatkan kinerja, kerja sama tim yang baik juga dapat meningkatkan prestasi dan produktivitas kerja (Kreitner \& Kinicki, 2005)

Kenyataan yang terjadi di lapangan menunjukkan bahwa di sekolah MTs JB ditemukan kurangnya kerja sama antar sesama guru dalam mencapai visi misi sekolah. Guru-guru di sekolah ini kurang memiliki tim kerja yang baik. Hal ini dapat dilihat dari hasil observasi selama praktek kerja profesi bahwa guru-guru di sini kurang memiliki komunikasi yang baik antar sesama guru. Misalnya seorang guru yang tidak masuk sekolah tidak menyampaikan ke guru lain. Akibatnya, tidak ada yang membantu untuk memberikan tugas kepada siswa yang saat itu kelasnya diampu oleh guru yang tidak masuk. Hal tersebut juga menunjukkan kalau guru tidak melakukan komunikasi dengan rekan kerjanya yang lain untuk meminta bantuan agar digantikan dalam mengajar.

Di dalam organisasi sekolah sebaiknya guru saling melakukan komunikasi agar dapat saling membantu untuk mencapai tujuan sekolah. Dengan melakukan komunikasi guru dapat saling membantu dalam menyelesaikan permasalahan, saling berbagi tanggung jawab, dan membagi informasi untuk mempelajari keterampilan baru.

Selain masalah komunikasi, permasalahan di atas juga menunjukkan bahwa antar sesama guru tidak saling membantu dalam mengerjakan tugas mereka sebagai guru. Ini menunjukkan bahwa guru tidak memiliki backup behavior antar sesama rekan kerja. Masalah komunikasi juga terjadi jika ada permasalahan yang terkait dengan kebijakan sekolah, misalnya pada saat ada salah satu siswa yang akan dikeluarkan dari sekolah. Ada beberapa guru yang merasa guru lain tidak memiliki komunikasi secara terbuka sehingga tidak mempedulikan pendapat mereka dan langsung mengambil sebuah keputusan dengan tidak jadi mengeluarkan siswa tersebut dari sekolah. Padahal saat itu ada beberapa guru yang merasa siswa tersebut perlu dikeluarkan karena menganggu proses belajar mengajar di sekolah, sehingga guru tersebut merasa pendapatnya tidak diperhatikan. Hal ini juga memperlihatkan bahwa guru-guru di sekolah kurang memiliki komunikasi yang terbuka, yang akhirnya membuat mereka saling kurang peduli satu sama lain.

Dari hasil penyebaran skala terbuka, ada enam guru (40\%) dari 15 guru di MTs JB yang menuliskan bahwa mereka memiliki masalah dengan guru yang lain. Guru-guru di MTs JB ini 
menuliskan bahwa masih ada rasa saling iri dengan guru yang lain, dan ada yang menuliskan kalau terkadang guru "mengurusi masalah guru yang lain" dan tidak mengurus masalahnya sendiri. Hal ini sesuai dengan yang diungkapkan Surana (2010) bahwa lingkungan non fisik, yaitu rekan kerja di mana adanya upaya untuk saling menjatuhkan, saling menjelekkan, dan lain-lain mengakibatkan menjadi kurang bergairah dan nyaman dalam menjalankan pekerjaan sebagai pengajar. Robbins (Surana, 2010) mengatakan apabila dalam lingkungan kerja ada saling perhatian, dapat bekerja sama dengan baik, maka akan menumbuhkan semangat kerja.

Menurut Dee dan Henkin (Risfandy \& Suprapti, 2009), ada empat fungsi utama tim kerja guru, yaitu pengajaran, pengembangan kurikulum, penguasaan administrasi sekolah, dan hubungan komunitas sekolah. Tim pengajar merupakan kelompok kecil yang berkolaborasi untuk membentuk lingkungan pengajaran atau pembelajaran.Tim pengembangan kurikulum bertugas menguji dan merevisi isu instruksional dan pendekatan yang berkaitan dengan pendidikan.Tim penguasaan atau administrasi sekolah bertugas mengembangkan anggaran, menetapkan tujuan kurikuler, dan menetapkan rencana panjang untuk sekolah.

Kenyataan yang terjadi pada MTs
JB, kurangnya tim kerja guru akhirnya membuat empat fungsi utama tim kerja guru di sekolah kurang berjalan dengan baik. Guru-guru di MTs ini tidak melakukan pengajaran sesuai dengan peraturan seperti saling menggantikan saat ada yang tidak masuk dan tidak ada usaha saling membantu antar sesama guru. Penguasaan administrasi sekolah juga hanya dikerjakan oleh yang bertugas dan tidak ada saling membantu sehingga masih ada sikap saling iri. Seperti saat pelaksanaan proses akreditasi sekolah, ada beberapa guru yang mengerjakan dan ada guru yang tidak peduli sehingga tidak ikut membantu. Pada pengembangan kurikulum juga terjadi hal sama, pengembangan kurikulum juga hanya dikerjakan oleh guru bagian kurikulum, tapi kurikulum yang dikembangkan juga tidak bisa dilaksanakan karena guru-guru yang lain tidak ikut melaksanakannya. Pada saat wawancara dengan kepala madrasah dan guru bimbingan konseling, terungkap kalau guru-guru tidak memiliki komitmen yang sama untuk menjalankannya padahal mereka harus bersama-sama untuk dapat mencapai tujuan sekolah. Hal ini akhirnya berdampak pada tidak tercapainya tujuan sekolah seperti tidak adanya pengadaan remedial, jam sekolah wajib yang tidak dapat terpenuhi, kompetensi peserta didik yang tidak tercapai karena jam kelas banyak kosong tidak ada gurunya, jam mengajar guru yang tidak tercapai yang 
harusnya setiap guru harus memenuhi standar pelayanan minimal 37,5 jam seminggu, dan penguasaan guru terhadap kelas juga kurang. Selain itu terkait dengan prestasi sekolah. Sekolah ini belum mendapatkan prestasi di luar sekolah. Sedangkan untuk lulusan dari sekolah MTs JB tahun 2011, siswa kelas IX dinyatakan lulus semua. Walaupun menurut guru bimbingan konseling, siswa di sini lulus karena nilainya banyak dibantu oleh guru.

Berdasarkan beberapa penelitian yang sudah dilakukan diketahui tim kerja di sekolah sangat penting, namun yang terjadi tim kerja antar sesama guru di MTs JB kurang efektif. Berdasarkan hasil wawancara dengan guru-guru di MTs JB kurang efektifnya tim kerja guru di sekolah ini dikarenakan beberapa hal, yaitu kurang tegasnya kepala madrasah. Ada yang mengatakan tidak ada deskripsi pekerjaan yang jelas untuk setiap guru dengan jabatannya masing-masing sehingga menimbulkan sikap iri antar sesama guru, perbedaan karakter dan perbedaan latar belakang pendidikan, kurangnya koordinasi antar sesama guru dalam melaksanakan tanggung jawab sebagai guru maupun anggota organisasi sekolah, dan kurangnya keterbukaan, sikap saling menerima dan saling menghargai antara rekan kerja.

Hal ini sesuai dengan yang diungkapkan oleh Maas (2004), faktorfaktor yang yang dapat merupakan sumber konflik, yaitu perbedaan keinginan, nilai, tujuan, adanya keterbatasan akan sumber tertentu seperti kekuasaan, kedudukan, waktu, popularitas, uang dan lain-lain, serta persaingan. Kerugian yang ditimbulkan oleh konflik biasanya disebabkan konflik tersebut dibiarkan berjalan dalam waktu yang lama dan berkepanjangan atau dibiarkan menjadi semakin meruncing tanpa ada penyelesaian. Tentu hal ini dapat merusak iklim kerja dan pada akhirnya akan berpengaruh pada kinerja kelompok. Selain itu DeLuca dan Valacich (Nejati dkk, 2010) mengungkapkan ada berbagai faktor yang memengaruhi kinerja tim, termasuk ukuran tim, anggota tim, latar belakang dan budaya, komunikasi yang baik antara anggota tim, dan lain-lain. Pendapat lain diungkapkan oleh Soekamto, Pidarta, Goldhabert (Sardinah, 2009) bahwa faktor-faktor yang memengaruhi iklim kerja sama di sekolah meliputi komitmen, komunikasi interpersonal, gaya kepemimpinan, penempatan, rasa aman, penghargaan, lingkungan kerja dan konflik. Dari hal ini diketahui bahwa permasalahan kurangnya keefektifan tim kerja guru-guru yang ada di MTs JB ini disebabkan oleh berbagai hal. Dalam hal ini diperlukan adanya intervensi untuk meningkatkan efekivitas tim kerja guru MTsJB.

Pelatihan merupakan intervensi yang diberikan untuk meningkatkan tim kerja guru-guru MTs JB. Pelatihan berfokus kepada kerja sama tim untuk 
menggabungkan pengetahuan dan keterampilan dalam permainan tim yang efektif (Smith, 2009). Peneliti bertujuan untuk memberikan intervensi peningkatan tim kerja melalui sebuah pelatihan outbound kepada guru-guru MTs JB. Aryani dan Suprianto (2003) dalam penelitiannya menunjukkan bahwa metode arung alam ini dapat meningkatkan tim kerja perawat. Hal ini juga diungkapkan oleh Laabs (1991) bahwa pelatihan di luar ruangan dengan memberikan tantangan dapat meningkatkan suatu tim. Hal serupa diungkapkan Priest dan Gass (2006) dengan pelatihan dengan metode belajar dari pengalaman ini dapat memberikan perubahan yang positif pada tim kerja dalam sebuah organisasi.

Menurut Ancok (2002), berbagai alasan untuk menggunakan metode pelatihan outbound adalah metode ini merupakan sebuah simulasi kehidupan yang kompleks yang dibuat menjadi sederhana. Metode ini menggunakan pendekatan metode belajar melalui pengalaman (experiential learning). Metode ini penuh kegembiraan karena dilakukan dengan permainan. Ancok (2002) mengatakan kehidupan dalam organisasi yang sangat kompleks sebenarnya dapat disimulasikan ke dalam suatu bentuk kegiatan sederhana. Permainan dalam kegiatan outbound ini adalah cara untuk menggambarkan kehidupan yang kompleks dengan cara sederhana melalui penggunaan sebuah metafora. Hal ini sesuai dengan yang diungkapkan Widyarti (2006) untuk meningkatkan anggota atau staf dalam suatu organisasi atau perusahaan dalam hal kerja sama dalam satu tim (teamwork), tidak cukup bila hanya diberikan pembekalan dan pengarahan dalam bentuk teori atau pengetahuan saja. Salah satu upaya yang dapat ditempuh adalah melalui training atau pelatihan yang memanfaatkan kelebihan alam (Outbound Training) sehingga membebaskan kembali semua kungkungan dan beban pegawai atas sebuah pekerjaan. Pelatihan outbound ini dapat meningkatkan kemampuan pegawai untuk bekerja dalam tim, dapat meningkatkan motivasi dan keyakinan diri akan kemampuan diri serta mampu berpikir kreatif, mampu meningkatkan kebersamaan dan rasa saling percaya, dan berupa penyegaran dan memecahkan kekakuan berorganisasi (Ancok, 2002).

Oleh karena itu, peneliti tertarik melakukan penelitian untuk mengetahui pengaruh pelatihan outbound dalam meningkatkan tim kerja guru MTs JB. Hipotesis yang diajukan dalam penelitian ini adalah pelatihan outbound dapat meningkatkan kerja guru di sekolah.

\section{METODE PENELITIAN}

\section{Subjek Penelitian}

Subjek penelitian ini adalah guru 
MTs JB yang terdiri dari enam guru lakilaki dan sembilan guru perempuan. Guru-guru di MTs JB ini memiliki usia antara 22 tahun sampai 54 tahun.

\section{Desain Penelitian}

Penelitian ini menggunakan metode pre experimental design atau juga sering dikenal dengan quasi experiment. Bentuk rancangan eksperimen yang digunakan adalah the one group pretest-posttest design. Pelaksanaan eksperimen ini menggunakan desain kelompok tunggal dengan prates dan pascates yang dilakukan dengan cara melakukan percobaan terhadap satu kelompok, tanpa menggunakan kelompok pembanding (Shaughnessy dkk, 2007). Pengukuran tim kerja guru juga dilakukan kembali dua minggu setelah pelatihan (follow up) dengan menggunakan skala yang sama dengan prates dan pascates. Selain itu tim kerja guru juga akan diukur oleh observer yang akan mengisi skala tim kerja guru sebelum dan sesudah pelatihan agar tidak menimbulkan social desirability.

Adapun rancangan penelitian dapat dilihat pada gambar berikut:

\section{$\mathrm{O} 1 \times \mathrm{O} 2$}

Gambar 1. Rancangan penelitian Keterangan :

O1:Kuisioner sebelum diberikan pelatihan outbound
$X \quad$ :Intervensi (pelatihan outbound)

O2:Kuesioner setelah diberikan pelatihan outbound

\section{Metode Pengumpulan Data}

Metode pengumpulan data adalah cara-cara yang dipergunakan untuk memperoleh data yang dipergunakan untuk memperoleh data untuk mencapai tujuan penelitian. Adapun metode pengumpulan data yang digunakan dalam penelitian ini adalah skala, wawancara, dan observasi.

1. Skala

Skala merupakan daftar pertanyaan yang harus diisi oleh orang yang diukur (responden). Sedangkan yang digunakan pada saat observasi awal untuk mengetahui permasalahan guru di sekolah adalah menggunakan angket terbuka. Setelah mengetahui permasalahan yang ada di sekolah dilanjutkan dengan menggunakan skala yang sesuai dengan permasalahan guru, yaitu skala tim kerja guru di sekolah. Skala yang digunakan untuk prates dan pascates merupakan tes yang sama, dimaksudkan supaya tidak ada pengaruh perbedaan kualitas instrument terhadap perubahan pengetahuan dan pemahaman yang terjadi. Skala ini disusun berdasarkan indikator tim kerja guru menurut Park (2005), yaitu 
komunikasi, tim orientasi, pemantauan, umpan balik, backup behavior, koordinasi, dan kepercayaan. Jumlah pernyataan yang terdapat pada Skala penelitian ini sebanyak 57 aitem.

Skala tim kerja guru ini menggunakan skala likert di mana pernyataan favorable memiliki rentang angka dari satu sampai tujuh untuk sangat tidak sesuai sampai dengan pernyataan sangat sesuai. Semakin besar angka yang dipilih menunjukkan bahwa semakin sangat sesuai dengan pernyataan. Sebaliknya untuk pernyataan unfavorable ada rentang angka dari tujuh sampai satu dengan pernyataan sangat tidak sesuai sampai dengan penyataan sangat sesuai. Semakin sangat sesuai dengan pernyataan maka semakin kecil angka yang dipilih.

Skala untuk evaluasi reaksi dan evaluasi pengetahuan yang dilakukan untuk mengetahui apakah peserta menyukai program pelatihan dan pengetahuan apa yang telah dipelajari peserta.

\section{Wawancara}

Wawancara digunakan untuk mengumpulkan data dengan mengajukan pertanyaan-pertanyaan kepada responden (Tanzeh \& Suyitno, 2006). Wawancara di sini digunakan sebagai data pelengkap penelitian. Instrumen wawancara berbentuk uraian yang ditujukan kepada guru dengan maksud untuk mengetahui permasalahan guru di sekolah. Data yang terkumpul dianalisis sebagai dasar untuk penelitian. Wawancara dilakukan sebelum mendapat pelatihan (baseline) dan setelah mendapat pelatihan (follow up). Hal-hal pokok yang ditanyakan pada pada saat sebelum pelatihan (baseline), yaitu fokus pada permasalahan yang dimiliki guru di sekolah terkait dengan tugas guru, interaksi antara sesama guru, pekerjaan yang dilakukan guru dan apa yang menyebabkan permasalahan guru. Sedangkan hal-hal pokok yang ditanyakan setelah pelatihan (follow up) adalah mengenai apa saja perubahan yang dirasakan setelah pelatihan, apakah pelatihan yang dilaksanakan sudah dapat menyelesaikan permasalahan guru, bagaimana interaksi antar sesama guru, dan bagaimana guru dapat saling bekerja sama dalam pekerjaan mereka sebagai guru.

3. Observasi

Menurut Hadi (Tanzeh \& Suyitno, 2006), observasi bisa diartikan sebagai pengamatan dan pencatatan secara sistematis tentang fenomena-fenomena yang diteliti. Observasi berguna untuk mengetahui aktivitas guru selama di sekolah. Obsevasi dalam penelitian 
ini dimaksudkan untuk mengetahui sejauh mana tim kerja guru di sekolah dalam melaksanakan fungsi tim kerja guru di sekolah. Observasi dilakukan di sekolah sebelum pelatihan (baseline), masa pelatihan (intevensi) dan sesudah pelatihan (masa follow-up).Panduan observasi ini disusun berdasarkan indikator tim kerja guru menurut Park (2005), yaitu komunikasi, tim orientasi, pemantauan, umpan balik, backup behavior, koordinasi, dan kepercayaan. Observasi sebelum pelatihan (baseline) menggunakan metode anecdotal record, sedangkan observasi yang digunakan saat pelatihan (intervensi) dan setelah pelatihan (masa followup) menggunakan metode rating scale. Hal-hal pokok yang diobservasi adalah perilaku guru saat bekerja sama dengan guru lain terkait dengan bagaimana guru melakukan pekerjaannya seperti mengajar, mengerjakan administrasi sekolah, melakukan hubungan dengan guru dan orang tua, dan mengembangkan kurikulum.

\section{Prosedur Intervensi}

Sebelum pelaksanaan intervensi terlebih dahulu dilakukan prates dengan menggunakan skala yang sudah diuji coba. Selain prates juga akan dilakukan penandatanganan informed consent oleh guru-guru Madrasah Tsanawiyah "JB" dan penjelasan mengenai apa saja yang perlu dipersiapkan untuk mengikuti pelatihan.

Program pelatihan outbound berlangsung selama dua hari satu malam dengan rincian terdiri dari 10 sesi dan setiap sesinya membutuhkan waktu \pm 60 menit sampai \pm 90 menit. Pada setiap selesai satu permainan dilakukan debrief yang membutuhkan waktu \pm 30 menit. Saat malam hari ada diskusi di mana guru saling mengungkapkan pemasalahan mereka yang kemudian dilanjutkan dengan refleksi yang membutuhkan waktu \pm 120 menit. Pada hari pertama, pembukaan dan stretching, permainan blind lead, permainan pipa bocor, relaksasi dan refleksi. Hari kedua, sholat subuh berjamaah, persiapan, stretching, makan pagi, dilanjutkan permainan all stand up, permainan drop egg, permainan atomic bomb, permainan trust fall, terakhir evaluasi dan penutup. Namun pelatihan outbound tidak dapat berjalan sesuai dengan perencanaan awal yang dilaksanakan dua hari satu malam. Pelatihan outbound berjalan satu hari satu malam dan ada dua permainan yang tidak dimainkan. Hal ini dikarenakan guru-guru di sekolah itu memiliki kesibukan masing-masing pada hari kedua. Melalui kesepakatan peneliti, guru-guru dan trainer, akhirnya pelatihan outbound diselesaikan satu hari sampai materi yang disampaikan dipandang cukup oleh trainer dan peserta, yang juga didiskusikan dengan peneliti. 
Menurut Seniati dkk (2005), jika pelaksanaan penelitian tidak sejalan dengan perencanaan, maka dalam laporan penelitian perlu disampaikan mengapa penelitian tidak dapat sesuai dengan perencanaan. Pada penelitian ini terjadi experimental mortality di mana jumlah subjek pada akhir penelitian berkurang dibandingkan dengan awal penelitian (Seniati dkk, 2005). Pada penelitian ini subjek memiliki kesibukan masing-masing pada hari kedua sehingga subjek tidak bersedia mengikuti pelatihan sampai hari kedua dan diselesaikan satu hari saja. Validitas internal dalam penelitian ini bisa saja menjadi rendah karena tidak bersedianya subjek mengikuti jadwal pelatihan yang sudah direncanakan dari awal dan tidak ada cara yang dapat dilakukan untuk mengatasi faktor ini (Seniati dkk, 2005). Selain itu terjadi juga faktor yang memengaruhi validitas eksperimental, yaitu multiple-treatment interference di mana perlakukan yang diberikan tidak sesuai dengan perencanaan awal (Seniati dkk, 2005).

\section{Metode Analisis Data}

Analisis data yang digunakan untuk pengujian hipotesis penelitian ini adalah dengan analisis statistik, karena statistik bekerja dengan angka-angka yang bersifat objektif dan universal. Teknik analisis data yang digunakan adalah analisis kuantitatif dengan two related sample test dengan uji wilcoxon.
Uji tanda merupakan bagian dari statistik non parametrik yang menguji dua sampel yang saling berhubungan (Priyatno, 2012). Selain itu dilakukan juga analisis data dengan cara visual inspection. Analisis ini dilakukan untuk melihat kemampuan individu bekerja sama dalam tim sebelum dan sesudah diberi intervensi.

\section{HASIL PENELITIAN}

\section{Deskripsi Data Penelitian}

Subjek yang dapat diambil datanya berjumlah delapan orang. Peserta yang mengikuti pelatihan dari awal sampai akhir pelatihan berjumlah sembilan orang, tetapi ada satu orang yang keluar dari sekolah sehingga tidak dapat dilakukan pengukuran. Sedangkan untuk tiga orang peserta lainnya yang mengikuti pelatihan tidak dapat dilakukan pengukuran karena tidak mengikuti pelatihan outbound dari awal sampai akhir pelatihan yang dilakukan di Pusat Studio Audio Visual pada tanggal 22 Juni 2012.

Data ini disusun berdasarkan pengisian Skala Tim kerja guru sebelum pelatihan, setelah pelatihan diberikan dan setelah dua minggu pelatihan (follow up). Dari data ini dapatlah diketahui tingkat tim kerja guru secara individu sebelum pelatihan, sesudah pelatihan dan dua minggu setelah pelatihan. Sebagai tambahan data dilakukan observasi dengan menggunakan metode 
rating scale pada peserta pada saat pelatihan dan dua minggu setelah

pelatihan (follow up). Data dapat dilihat pada Tabel 1 berikut ini.

Tabel 1. Data Skor Tim kerja guru dan Skor Rating Scale Observasi

\begin{tabular}{lccccc}
\hline \multirow{2}{*}{ Peserta } & \multicolumn{3}{c}{ Skor Skala } & \multicolumn{2}{c}{ Observasi } \\
\cline { 2 - 6 } & $\begin{array}{c}\text { Sebelum } \\
\text { Pelatihan }\end{array}$ & $\begin{array}{c}\text { Setelah } \\
\text { Pelatihan }\end{array}$ & $\begin{array}{c}\text { Follow } \\
\text { Up }\end{array}$ & $\begin{array}{c}\text { Saat } \\
\text { Pelatihan }\end{array}$ & $\begin{array}{c}\text { Follow } \\
\text { Up }\end{array}$ \\
\hline Subjek 1 & 288 & 302 & 303 & 141 & 157 \\
Subjek 2 & 248 & 225 & 269 & 151 & 152 \\
Subjek 3 & 239 & 249 & 239 & 124 & 148 \\
Subjek 4 & 255 & 283 & 306 & 125 & 158 \\
Subjek 5 & 235 & 230 & 240 & 132 & 155 \\
Subjek 6 & 223 & 270 & 281 & 141 & 164 \\
Subjek 7 & 237 & 267 & 256 & 127 & 147 \\
Subjek 8 & 226 & 226 & 235 & 124 & 142 \\
\hline
\end{tabular}

\section{Hasil Uji Hipotesis}

Analisis hasil dilakukan secara keseluruhan menggunakan analisis statistik uji dua sampel yang saling berhubungan (uji wilcoxon). Dari data prates dan pascates skala tim kerja guru diketahui nilai Sig 0,128 (nilai sig > 0,05 ) berarti hipotesis ditolak, yaitu tidak ada perbedaan tim kerja guru sebelum pelatihan (prates) dan setelah pelatihan outbound (pascates). Kemudian tim kerja guru dilihat lagi hasilnya dua minggu setelah pelatihan (follow up) diketahui nilai Sig 0,018 (nilai sig $<0,05$ ) yang berarti hipotesis diterima, yaitu ada perbedaan tim kerja guru sebelum pelatihan (prates) dan dua minggu setelah pelatihan (follow up). Selain melihat secara keseluruhan, dilakukan juga analisis data dengan cara visual inspection. Analisis ini dilakukan untuk melihat kemampuan individu dalam tim kerja sebelum dan sesudah diberi intervensi.

Dari delapan subjek, ada empat subjek yang mengalami peningkatan setelah pelatihan (pascates) dan memiliki konsistensi sampai dua minggu setelah pelatihan (follow up). Dua subjek mengalami penurunan setelah pelatihan (pascates), namun mengalami peningkatan dua minggu setelah pelatihan (follow up).Terakhir ada dua subjek yang mengalami peningkatan setelah pelatihan (pascates), namun mengalami penurunan dua minggu 
setelah pelatihan (follow up). padadiagramdibawahini:

Perbandingan skor tersebut dapat dilihat

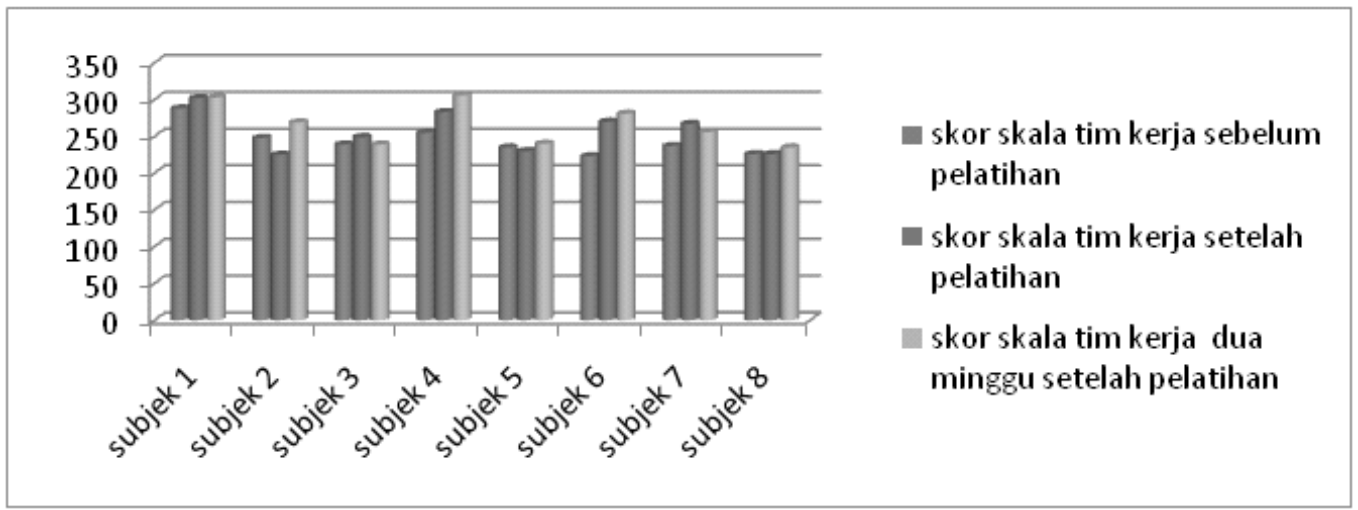

Diagram 1. Perbandingan skor skala tim kerja guru prates, pascates, dan dua minggu setelah pelatihan

Berdasarkan hasil observasi pelatihan sampai dua minggu setelah dengan menggunakan metode rating pelatihan. Perbandingan skor tersebut scale diketahui delapan subjek semua dapatdilihatpadadiagram dibawah ini: mengalami peningkatan dari saat

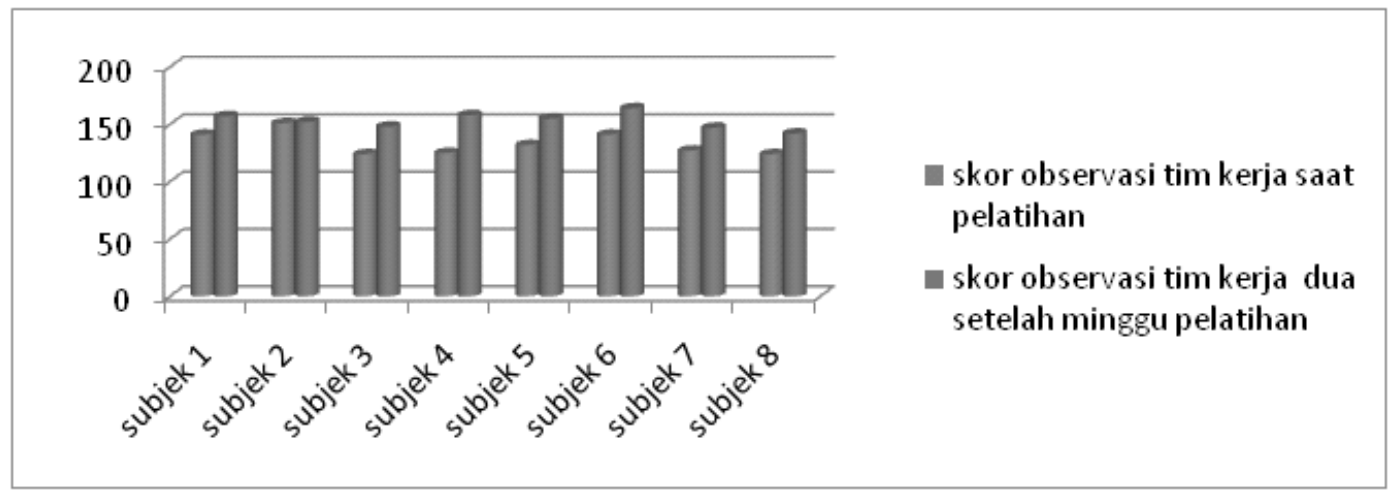

Diagram 2. Perbandingan skor observasi tim kerja guru saat pelatihan dan dua minggu setelah pelatihan

\section{PEMBAHASAN}

Pelatihan outbound merupakan bentuk pelatihan yang dilakukan di alam terbuka yang dirancang untuk meningkatkan tim kerja guru. Kuswoyo (2004) mengatakan pelatihan outbound merupakan kegiatan pelatihan alam terbuka yang menitikberatkan pada pembinaan sikap dan mental selaku pribadi dan anggota tim. Dalam pelatihan outbound ini konsekuensi dari semua keputusan dan tindakan yang diambil dirasakan langsung dan sangat nyata oleh 
peserta. Pada pelatihan outbound didasarkan pada prinsip pembelajaran experiential learning. Experiential learning sendiri terdiri atas lima tahapan, yaitu experiencing, publishing, processing, generalizing dan applying (Aryani dan Supriyanto, 2003).

Proses pelatihan outbound yang telah dilakukan dalam penelitian ini memberikan pengaruh pada tim kerja guru-guru MTs "JB". Pada saat pelatihan guru-guru baru merasakan tahapan experiencing, publishing, processing, generalizing, sehingga waktu proses pemberian skala pascates belum terlihat perubahan yang menonjol dalam tim kerja guru. Setelah pelatihan, guru-guru belum dapat mengaplikasikan apa yang mereka dapat dalam pelatihan dan tim kerja masih dalam tahap pemikiran dan hanya insight yang mereka dapat.

Selain itu pada saat pengisian skala pascates, tepat dilakukan selesai pelatihan pada malam hari, peserta saat itu sudah kelelahan dan hal tersebut memengaruhi pengisian skala pascates. Sedangkan dua minggu setelah pelatihan berjalan guru-guru sudah masuk pada tahapan applying. Mereka menerapkan komitmen yang telah mereka sepakati pada saat pelatihan. Hal ini terlihat saat setelah pelatihan, guru-guru setelah pelatihan mereka sedang menghadapi tahun ajaran baru dan harus bekerja sama untuk penerimaan siswa baru. Guru-guru di sini mulai membagi pekerjaan dan jabatan secara terbuka melalui proses rapat guru. Mereka melakukan komunikasi secara terbuka terkait keuangan, dan struktur organisasi yang saat itu masih dalam tahap musyawarah. Guru-guru juga selalu mengangkat tema kebersamaan yang sudah disepakati pada saat pelatihan ketika menjalankan tugasnya bersama-sama saat menghadapi tahun ajaran baru dan dapat bersikap saling terbuka satu sama lain ketika ada permasalahan. Kemudian diketahui hasil pengukuran dua minggu setelah pelatihan (follow up) diketahui ada peningkatan skor skala tim kerja guru di sekolah, sehingga diketahui bahwa pelatihan outbound memiliki pengaruh untuk meningkatkan tim kerja guru di sekolah.

\section{SIMPULAN DAN SARAN}

\section{Simpulan}

Berdasarkan analisis data dan pembahasan yang dilakukan, maka dapat disimpulkan bahwa pelatihan outbound dalam penelitian ini dapat meningkatkan tim kerja guru.

Hal ini dapat dilihat dari adanya peningkatan tim kerja guru di sekolah pada aspek komunikasi, kepemimpinan, orientasi tim, pemantauan, umpan balik, backup behavior, koordinasi, dan kepercayaan. Hal ini menunjukkan bahwa pelatihan outbound memberikan pengaruh bagi perubahan perilaku guru dalam tim kerja. 


\section{Saran}

Beberapa hal yang perlu disempurnakan agar pelatihan outbound pada penelitian-penelitian selanjutnya dapat memberikan hasil yang lebih optimal, antara lain sebagai berikut:

Saran untuk guru. Beberapa saran adalah (1) Guru diharapkan dapat konsisten dalam menjalankan komitmen yang sudah mereka buat saat pelatihan, (2) Guru diharapkan dapat selalu bersikap komunikatif dengan guru yang lain, sehingga tim kerja dapat berjalan dengan baik, dan (3) Guru diharapkan dapat membuat pertemuan-pertemuan lain yang sifatnya informal di luar pekerjaan sekolah, agar hubungan silaturahmi antar sesama guru tetap berjalan baik.

Saran untuk pihak sekolah. Beberapa saran adalah (1) Melihat tanggapan positif dari guru terhadap program pelatihan outbound untuk guru, maka sekolah diharapkan memiliki kerja sama dengan kalangan profesioanl yang ada, untuk menyelenggarakan program pelatihan terkait dengan kegiatan guru. (2) Memperbaiki struktur organisasi beserta deskripsi pekerjaan yang dimiliki oleh semua guru yang ada di sekolah. (3) Mengadakan rapat atau musyawarah dalam setiap pengambilan kebijakan sekolah.

Saran bagi psikolog. Beberapa saran adalah (1) Hasil penelitian ini selanjutnya dapat dijadikan dasar ilmiah untuk kajian program pelatihan outbound dalam suatu usaha preventif dan juga dalam usaha meningkatkan tim kerja dalam organisasi. (2) Program pelatihan outbound ini dapat ditetapkan sebagai penanganan pada organisasi yang kurang memiliki tim kerja.

Saran bagi peneliti selanjutnya. Beberapa saran adalah (1) Peneliti selanjutnya perlu mengupayakan agar semua guru dalam satu sekolah mengikuti pelatihan agar hasil pelatihan dapat lebih efektif dan optimal, karena tim kerja dilakukan bersama-sama tidak secara individu. (2) Peneliti selanjutnya sebaiknya benar-benar melakukan pendekatan personal dan memastikan kembali keikutsetaan guru dalam mengikuti pelatihan agar semua guru dapat hadir mengikuti pelatihan. (3) Peneliti selanjutnya tidak hanya berkomunikasi dengan kepala sekolah terkait dengan jadwal pelatihan tetapi juga dengan semua guru, jadi ketika kepala sekolah lupa untuk menyampaikan kepada guru yang lain, peneliti sudah memberitahukan kepada guru yang lain. (4) Peneliti selanjutnya sebaiknya menganalisis keandalan observasi guide, karena hasil observasi juga digunakan untuk analisis hasil data penelitian.

\section{DAFTAR PUSTAKA}

Ancok, D. (2002). Outbound Management Training.Yogyakarta: UII Press. 
Kreitner, R. \& Kinicki, A. (2005). Perilaku Organisasi. Jakarta: Penerbit Salemba Empat.

Kuswoyo, Y.E. (2004). Pengaruh Outbound Training Terhadap Kualitas Kerja Karyawan pada PT. Sengfang Moulding Perkasa Jombang.Skripsi tidak diterbitkan. Jombang: Fakultas Ekonomi Universitas Darul Ulum Jombang.

Laabs, J.J. (1991). Team Training Goes Outdoors. Personel Journal, 70 (6), 56-63.

Lundstorm,T., Pugliese,G., Bartley,J., Cox, J., \& Guither C. (2002). Organizational and Environmental Factors That Affect Worker Health and Safety and Patient Outcomes.The Association for Professionals in Infection Control and Epidemiology, 30 (2), 93-106. Detroit: Wayne State University.

Maas, L.T. (2004). Peranan Dinamika Kelompok dalam Meningkatkan Efektivitas Kerja Tim.Digitized by USU digital Library.Sumatera: Universitas Sumatera Utara.

Nejati, M., Nejati,M., \& Nami,B. (2010). Teamwork Approach An Investigation on Iranian Teamwork Attitudes. Canadian Social Science, 6 (3), 104-113.
Nielsen, L. T. (2008, August). Teamwork-The Best Way to avoid Professional Development?: A Cultural-Historical Activity Theory Approach to Understanding The Cultural Dynamics of Teamwork in an Organizational Context. Paper presented at European Conference on Educational Research, Helsinki, Finland.

Park,S., Henkin,A.B., Egley, R. (2005). Teacher Team Commitment, teamwork and Trust: Exploring Associations. Journal of Educational Administration 43 (4/5), 462- 479 .

Priest, S., \& Gass, M. A. (2006). The Effectiveness of Metaphoric Facilitation Styles in Corporate Adventure Training (CAT) Programs. Journal of Experiential Education, 29 (1), 78-94.

Priyatno, D. (2012). Belajar Praktis Analisis Parametrik dan Non Parametrik dengan SPSS. Yogyakarta: Penerbit Gava Media.

Risfandy, T dan Suprapti, A.R. (2009). Pengaruh Partisipasi di Tim Kerja pada Komitmen Organisasi dengan Pemberdayaan sebagai Pemediasi. Jurnal Bisnis dan Manajemen, 9 (1), 23-32. 
Sardinah. (2009). Iklim Kerja sama Guru Ditinjau dari Komitmen dan Komunikasi Interpersonal pada SD Negeri di Kecamatan Meuraxa Kota Banda Aceh.Jurnal Edukasi, 5 (1), 106-120. Aceh: Universitas Syiah Kuala.

Seniati,L., Yulianto, A., Setiadi, B.N. (2005). Psikologi Eksperimen. Jakarta: PT Tunas Jaya Lestari.

Shaughnessy, J.J., Eugene, Z.B., Jeanne, Z.S. (2007). Metodologi Penelitian Psikologi. Yogyakarta: Pustaka Pelajar.

Smith, G. (2009). Science Teacher Conceptions of Teams and Teamswork. Thesis. Queensland: Faculty of Education, Queensland University of Technology.

Suradi. (2005). Pengambilan Keputusan Bagi Para Manajer dalam Suatu Organisasi maupun Perusahaan. Jurnal Gema, 18 (33), 15-25. Universitas Negeri Surakarta.
Surana, M.R. (2010). Hubungan antara Kemampuan Manajerial Kepala Sekolah, Motivasi Guru, Lingkungan Kerja dan Komitmen Guru dengan Kinerja Guru di Kabupaten Bantul. Tesis (tidak diterbitkan). Yogyakarta: Pascasarjana Universitas Negeri Yogyakarta.

Tanzeh, A \& Suyitno. (2006). DasarDasar Penelitian. Surabaya: Lembaga Kajian Agama dan Filsafat (eLKAF).

Widyarti, W. (2006). Perbedaan Motivasi Kerja Karyawan Sebelum dan Sesudah Mendapatkan Pelatihan Outbound Pada PT. Astra Nissan Diesel Indonesia.Abstrak Skripsi (on line). Jakarta: Fakultas Psikologi Universitas Gunadarma. 